\title{
Adsorptive Performance of Soy Bran and Mustard Husk Towards Arsenic (V) Ions from Synthetic Aqueous Solutions
}

\author{
Doina Humelnicu, ${ }^{1, \star}$ Laurentiu Valentin Soroaga, ${ }^{1}$ Cecilia Arsene, ${ }^{1}$ \\ Ionel Humelnicu ${ }^{1}$ and Romeo Iulian Olariu ${ }^{1,2, *}$ \\ ${ }^{1}$ Alexandru Ioan Cuza" University of Iasi, Faculty of Chemistry, Bld. Carol I, nr. 11, Iasi, 700506, Romania \\ ${ }^{2}$ Alexandru Ioan Cuza" University of Iasi, CERNESIM, Bd. Carol I, nr. 11, Iasi, 700506, Romania \\ *Corresponding author: E-mail: doinah@uaic.ro,oromeo@uaic.ro, \\ phone: +40232201136
}

Received: $10-29-2018$

\begin{abstract}
Recently, there is growing attention on the use of low-cost sorbents in the depollution of contaminated waters. As a consequence, the present work investigates the potential of soy bran and mustard husk as possible sorbent for the removal of $\operatorname{arsenic}(\mathrm{V})$ from residual water. Effects of various operating parameters such as: contact time, $\mathrm{pH}$, initial arsenic concentration, $\mathrm{pH}$, sorbent dose, temperature were investigated to determine the removal efficiency of arsenic $(\mathrm{V})$. Thermodynamic parameters that characterize the process indicated that the adsorption is spontaneous and endothermic. The values for the separation factor, $R_{L}$ were less than one which confirms that the adsorption process was favorable. Equilibrium data fitted well to the Langmuir model with a higher adsorption capacity of soy bran $\left(74.07 \mathrm{mg} \mathrm{g}^{-1}\right)$ towards arsenic $(\mathrm{V})$ ions than mustard husk $\left(65.79 \mathrm{mg} \mathrm{g}^{-1}\right)$. It was found that the pseudo-second order kinetic model was the best applicable model to describe the adsorption kinetic data.
\end{abstract}

Keywords: Adsorption; arsenic; isotherm; soy bran; mustard husk

\section{Introduction}

Arsenic is an element that reaches into the environment from a variety of natural sources (volcanic emission, minerals) and anthropogenic activities (mining activities, burning of fossil fuels and the use of arsenical pesticides which have a longer residence time and also an increased capacity of accumulation. ${ }^{1-4}$

Also, by erosion, decomposition and due to the action atmospheric factors, arsenic can be released into groundwaters and surface waters. ${ }^{5,6}$

Stable inorganic arsenic species in water include arsenic acid anions $\left(\mathrm{H}_{2} \mathrm{AsO}_{4}{ }^{-}, \mathrm{H}_{3} \mathrm{AsO}_{4}, \mathrm{HAsO}_{4}{ }^{2-}\right.$ şi $\left.\mathrm{AsO}_{4}{ }^{3-}\right)$. Arsenious acid is also stable in water as $\mathrm{H}_{3} \mathrm{AsO}_{3}$ and $\mathrm{H}_{2} \mathrm{AsO}_{3}{ }^{-}$in moderately reducing conditions $(<200 \mathrm{mV}){ }^{7}$

Inorganic arsenic in oxidation states $+\mathrm{V}$ (arsenate) and +III (arsenite) is found in a variety of mineral in natural waters. Chemical arsenic behavior is related to the ease transformations between $+\mathrm{III}$ and $+\mathrm{V}$ oxidation states. The oxidation state affects the toxicity of arsenic compounds.
The toxicity of different arsenic species decreases in the order arsenite $>$ arsenate $>$ monomethylarsonate $>$ dimethylarsinate). ${ }^{8,9}$

There is clear evidence that chronic exposure to inorganic arsenic increases the risk of cancer. ${ }^{10}$ Studies have shown that inhalation of arsenic leads to an increased risk of lung cancer whereas the ingestion of arsenic has been associated with an increased possibility of skin cancer and cancer of the bladder, liver and lungs. ${ }^{11,12}$

Because of that in 2006 the World Health Organization (WHO) has decided to change the maximum admissible concentration of arsenic from $0.05 \mathrm{mg} / \mathrm{L}$ to $0.01 \mathrm{mg} / \mathrm{L}$ in drinking water. ${ }^{13}$

In order to eliminate arsenic from water has been used various methods: i) precipitation/co-precipitation, (method that allows the removal of arsenic up to 0.05 $\mathrm{mg} / \mathrm{L}$ and in some cases even less than $0.01 \mathrm{mg} / \mathrm{L})^{14,15}$; ii) membrane filtration (that may remove a variety of contaminants from water but for arsenic compounds this method can reduce their concentration up to $0.05 \mathrm{mg} / \mathrm{L}$. ${ }^{16} \mathrm{Howev}$ - 
er, this method presents some disadvantages, such as low efficiency, large amounts of waste and high cost, as well ${ }^{16}$; iii) ion exchange (method that are nowadays frequently used in the treatment of containing arsenic groundwater and drinking water because of its of high efficacy advantage. ${ }^{1,13,14,16-21}$ By using this method the level of the arsenic compounds in water is less than $0.01 \mathrm{mg} / \mathrm{L}$.

By adsorption, the contaminants are concentrated at the sorbent surface. Nature of the adsorption process could be explained based on two theories: one physical and one chemical.

Physical theory, the most widespread theory is the so-called potential theory or concentrated layer theory according to which the reaction between atoms that are found on the surface of the solid (adsorbent) and adsorbed molecules is determined by the van der Waals forces of attraction. Chemical theory of the adsorption admits the existence of a single monomolecular layer on the surface of the solid (adsorbent); adsorption forces act only on a very short distance which not exceeding the diameter of a molecule. 22

Thus, the adsorbent material must fulfill certain conditions such as: a type of particle size, high adsorption capacity, high selectivity, and high degree of adsorption, water strong physical connection, and low price.

In recent times, more attention is paid to cheap biomass such as powdered eggshell, ${ }^{23}$ pine leaves, ${ }^{24}$ rice husk. ${ }^{25}$

These biomasses appear to be a possible alternative for heavy metals removal due to their economic and environmental characteristics, the chemical composition, availability, low price, and high efficiency in removal of heavy metals from dilute solutions.

Recently, the need for an economical method for the removal of pollutants from contaminated waters involves researches on low cost sorbents such as agricultural waste by-products. In this regard, various type of agricultural waste by-products such as palm oil fruit shell, ${ }^{26}$ coffee grains,${ }^{27}$ fir tree sawdust, ${ }^{28}$ rose petals, ${ }^{29}$ rice husk, ${ }^{30}$ cellulose dust ${ }^{31}$ etc. have been investigated for the removal of the pollutants from the wastewaters.

The agricultural by-products may be different parts of plant, such as bark, stem, leaves, root, flower, fruit biomass, husk, hull, shell and may contain compounds such as cellulose, lignin, hemi-cellulose. These compounds have potential functional groups such as hydroxyl, carboxyl, amino, amido and alkoxy with a great affinity for the metal ions. $^{32}$

The aim of the present study is to analyse the sorption capacity of mustard husk soy bran as low cost agricultural by-products towards arsenic $(\mathrm{V})$ ions from the residual waters in different experimental conditions. During this study, effect of some parameters such as the dose of adsorbent, $\mathrm{pH}$, temperature, initial metal concentration and contact time were studied. Moreover, various isotherm and kinetic models were used to explain the adsorption process.

\section{Materials and Methods}

All chemicals were of analytical reagent grade and no further purification was carried out. The agricultural by-products used in these adsorption experiments were soy bran and mustard husk resulting from the milling and baking. Sorbents were collected from a local mill, ground, were prepared and characterized as shown by Humelnicu and colab. ${ }^{33}$

The stock solution containing the $\operatorname{arsenic}(\mathrm{V})$ was prepared from $\mathrm{Na}_{2} \mathrm{HAsO}_{4} 7 \mathrm{H}_{2} \mathrm{O}$ (Sigma-Aldrich). The adsorption experiments were performed in a batch system by stirring at $350 \mathrm{rpm}$ a suspension that contained arsenic $(\mathrm{V})$ ions solution and the sorbent. The $\mathrm{pH}$ values were in range 2 and 10, the initial concentration of the solution varied from 50 to $350 \mathrm{mg} \mathrm{L}^{-1}$, at a temperature between of $25^{\circ} \mathrm{C}$ $-45^{\circ} \mathrm{C}$, and the sorbent dose varied from 1.5 to $4 \mathrm{~g} \mathrm{~L}^{-1}$. The $\mathrm{pH}$ of the solution was adjusted with $\mathrm{NaOH}$ or $\mathrm{HNO}_{3}$ $0.1 \mathrm{M}$ solution and measured with a HANNA $\mathrm{pH} / \mathrm{tem}$ perature meter HI 991001.

After the equilibrium has been reached the supernatant was used for arsenic quantification by using Hydride Generation-Atomic Absorption Spectrometry (HG-AAS). HG-AAS is powerful analytical techniques that provide information of the level of concentrations of As with low interferences and a lower LOQ because the analyte is separated from the sample matrix before the quantification. ${ }^{34,35}$ Experiments were conducted on a High Resolution Continuous Source Spectrometer ContrAA 700 (Analytik Jena).

The amount of arsenic adsorbed per unit mass by the sorbent under equilibrium conditions was calculated by the equation (1).

$$
\mathrm{q}=\frac{\left(\mathrm{C}_{0}-\mathrm{C}_{\mathrm{e}}\right) \cdot \mathrm{V}}{\mathrm{m}},(\mathrm{mg} \text { As/g sorbent })
$$

where: $\mathrm{C}_{0}$ is initial concentration of solution, $\left(\mathrm{mg} \mathrm{L}^{-1}\right), \mathrm{C}_{\mathrm{e}}$ is equilibrium $\mathrm{As}(\mathrm{V})$ concentration $\left(\mathrm{mg} \mathrm{L}^{-1}\right), \mathrm{V}$ is volume of solution (L), and $\mathrm{m}$ is sorbent mass $(\mathrm{g})$.

The distribution coefficient, $K_{d}$, is defined as the ratio of the concentration of arsenic retained in the sorbent and the one in the solution at equilibrium being calculated with equation (2).

$$
\mathrm{K}_{\mathrm{d}}=\frac{\left(\mathrm{C}_{0}-\mathrm{C}_{\mathrm{c}}\right)}{\mathrm{C}_{\mathrm{c}}} \cdot \frac{\mathrm{V}}{\mathrm{m}} \quad\left(\mathrm{mL} \cdot \mathrm{g}^{-1}\right)
$$

where $\mathrm{C}_{0}, \mathrm{C}_{\mathrm{e}}, \mathrm{V}$ and $\mathrm{m}$ have the same meaning as in $\mathrm{Eq}$ (1).

The adsorption capacities of the two adsorbent were analyzed through the use of Langmuir, Freundlich, Temkin and Flory-Huggins models. The kinetics of arsenic adsorption on the soy bran and mustard husk were analyzed by using pseudo first-order, pseudo second-order, and intra-particle diffusion kinetic models. 
Desorption experiments were carried out in batch system by using the sorbent loaded with arsenic immediately after the adsorption processes.

Four common eluents have been tested, namely: $\mathrm{NaOH}, \mathrm{NaHCO}_{3}, \mathrm{HCl}$ and $\mathrm{HNO}_{3} 0.01 \mathrm{M}$. The sorbent loaded with As and eluent solution was kept in contact for 24 hours.

The following abbreviations have been used: M-mustard husk, S-soy bran, As-M- mustard husk after As(V) adsorption and As-S-soy bran after $\mathrm{As}(\mathrm{V})$ adsorption, respectively.

\section{Results and Discussion}

\section{1. pH Effect on the Adsorption Process}

$\mathrm{pH}$ is one of the most important factor that influences the chemistry of arsenic in aqueous solution and surface of the adsorbents. The effect of $\mathrm{pH}$ on the adsorption process of As on the mustard husk and soy bran was investigated in the range of values between 2-10. Figure 1 illustrates the effect of $\mathrm{pH}$ on $\mathrm{As}(\mathrm{V})$ adsorption on the studied adsorbents. The amount of retained $\mathrm{As}(\mathrm{V})$ increased slightly with increasing $\mathrm{pH}$ and reached a maximum value at $\mathrm{pH} 6$, after that decreased slightly. Consequently, in further experiments $\mathrm{pH} 6$ value was selected as an optimum $\mathrm{pH}$ condition.

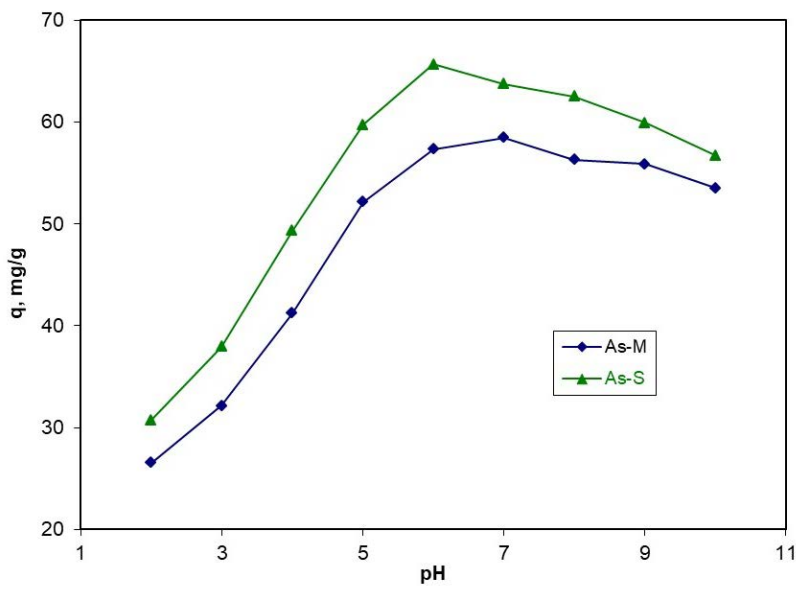

Figure 1. $\mathrm{pH}$ dependence of $\operatorname{arsenic}(\mathrm{V})$ adsorption on mustard husk and soy bran.

The possible centers on the surface of the sorbents that could be responsible for the adsorption include - $\mathrm{OH}$ and $-\mathrm{COOH}$ functional groups. ${ }^{36}$ Mamindy-Pajany et al. ${ }^{37}$ denotes that in according to the arsenic speciation, $\mathrm{H}_{2} \mathrm{AsO}_{4}{ }^{-}$is predominant for $\mathrm{pH}$ values between 2 and 5 , whereas $\mathrm{HAsO}_{4}{ }^{2-}$ is predominant for $\mathrm{pH}$ values between 7 and 10 . On the other hand, at higher $\mathrm{pH}$ condition active centers were not protonated and were both neutral and anionic by releasing $\mathrm{H}^{+}$ions $\left(-\mathrm{COO}^{-},-\mathrm{O}^{-}\right)$which leads to a less adsorption.

\section{2. Effect of Sorbent Dosage}

The adsorption process is efficient if it requires a small amount of sorbent. Effect of sorbent dosage on $\mathrm{As}(\mathrm{V})$ adsorption was investigated by changing the sorbent dose from 1.5 to $4 \mathrm{~g} \mathrm{~L}^{-1}$ with the initial metal concentration $250 \mathrm{mg} \mathrm{L}^{-1}$ at $\mathrm{pH} 6.0$, temperature of $25^{\circ} \mathrm{C}$ and contact time $60 \mathrm{~min}$. Figure 2 shows that the adsorption capacity increases with the increase of adsorbent dose from 1.5 to $3.5 \mathrm{~g} \mathrm{~L}^{-1}$ followed by a slightly decrease. Increase of the adsorption capacity was due to the greater availability of the exchangeable sites or surface area at the higher concentrations of the adsorbent.

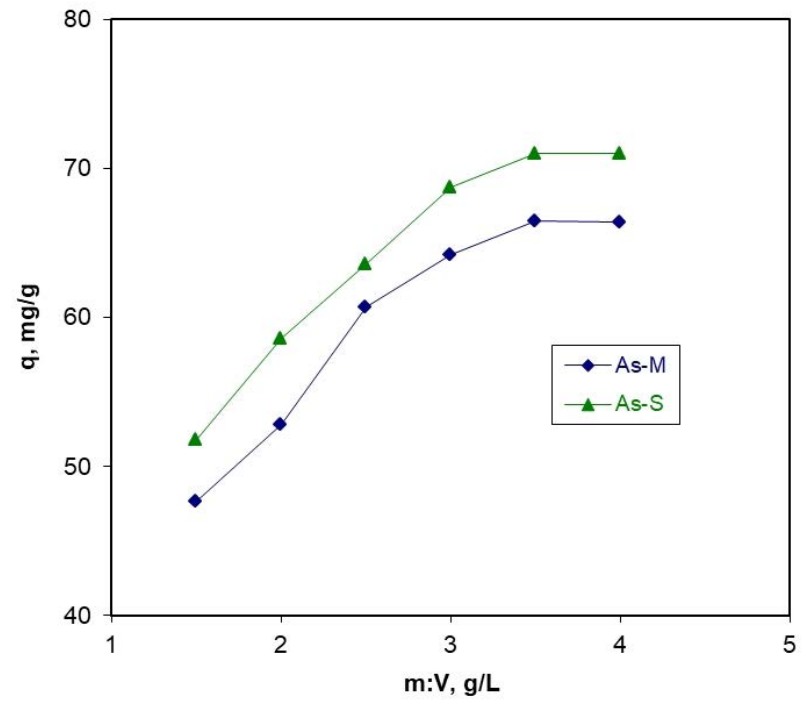

Figure 2. Effect of sorbent dosage on the adsorption process of $\mathrm{As}(\mathrm{V})$ on the mustard husk and soy bran.

From the experimental results it was found that the adsorption process has higher efficiency in the case of soy bran as adsorbent in comparison with mustard husk.

\section{3. Effect of Contact Time on the Adsorption Process of As $(\mathrm{V})$}

Influence of the contact time on the adsorption process of $\mathrm{As}(\mathrm{V})$ ions on the two sorbents has been studied for a period time between 15 to 180 minutes, all the other parameters being kept constant. In these studies the As ions concentration have been varied from $50 \mathrm{mg}$ $\mathrm{L}^{-1}$ to $250 \mathrm{mg} \mathrm{L}^{-1}$. The obtained results are depicted in Figure 3.

The results indicate that the amount of the retained ions increases with the increasing of the contact time and the equilibrium is reached after about 75 minutes. From Figures 3 on can conclude that the adsorption of As is more effective on soy bran as adsorbent. 
a)

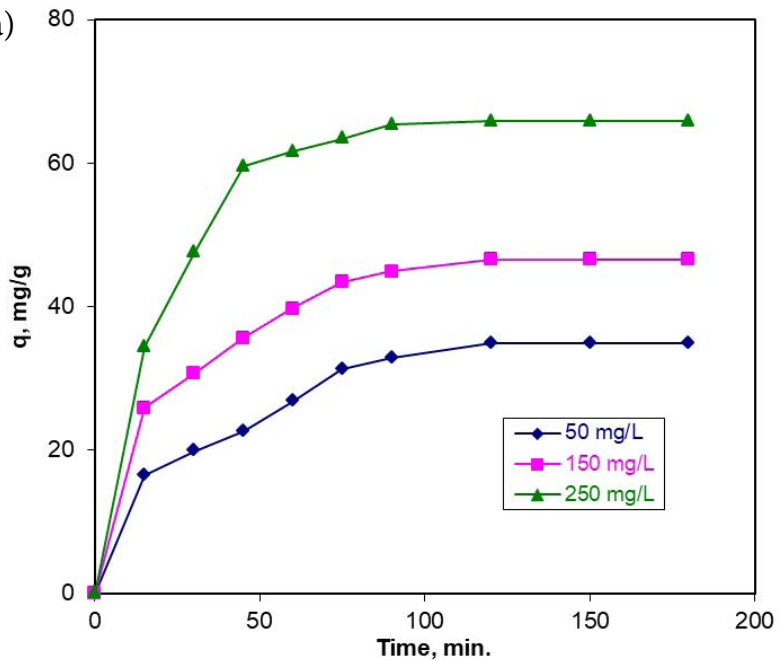

b)

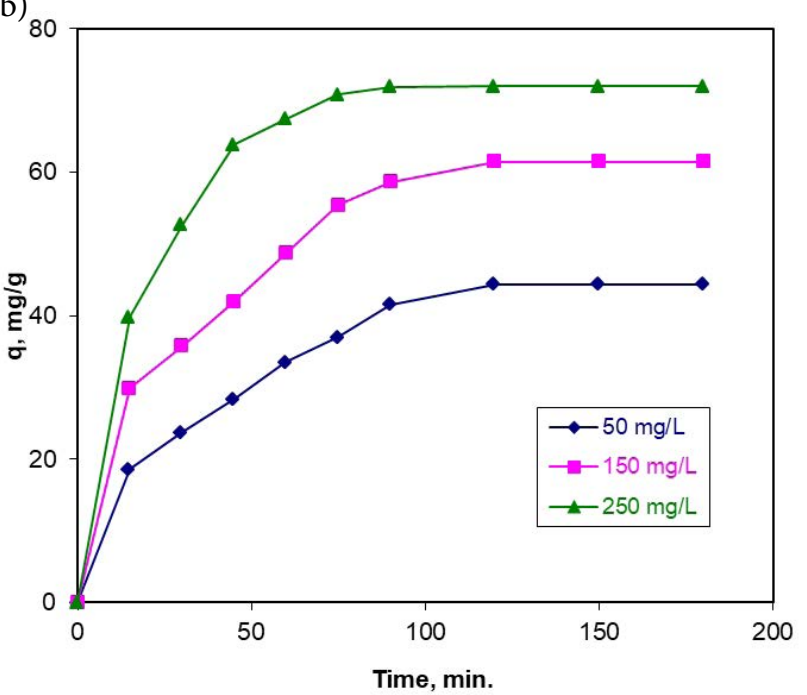

Figure 3. Contact time dependence of adsorption process of As $(\mathrm{V})$ on: a) mustard husk, b) soy bran.

\section{4. Effect of As(V) Initial Concentration on the Adsorption Process}

The effect of the initial concentration of the $\mathrm{As}(\mathrm{V})$ solution on the adsorption has been investigated, too. The initial concentration was varied from 25 to $350 \mathrm{mg} \mathrm{L}^{-1}$, all other parameters have been maintained constant. Figure 4 shows that the adsorption capacity increases with the increasing of the initial concentration of $\mathrm{As}(\mathrm{V})$. Thus, for mustard husk adsorption capacity increases form 31.25 to $59.47 \mathrm{mg} \mathrm{g}^{-1}$ and for soy bran from 36.98 to $70.39 \mathrm{mg} \mathrm{g}^{-1}$. In both cases after $250 \mathrm{mg} \mathrm{L}^{-1}$ as initial $\mathrm{As}(\mathrm{V})$ concentration the adsorption capacities decrease. These results are in good agreement with Asif and Chen ${ }^{25}$ that explained this variation due to a raise in the driving force of the concentration gradient and low concentration, the driving force of adsorbent is reduced due to low concentration gradient. In the diluted solutions the mobility of ions is high, and for

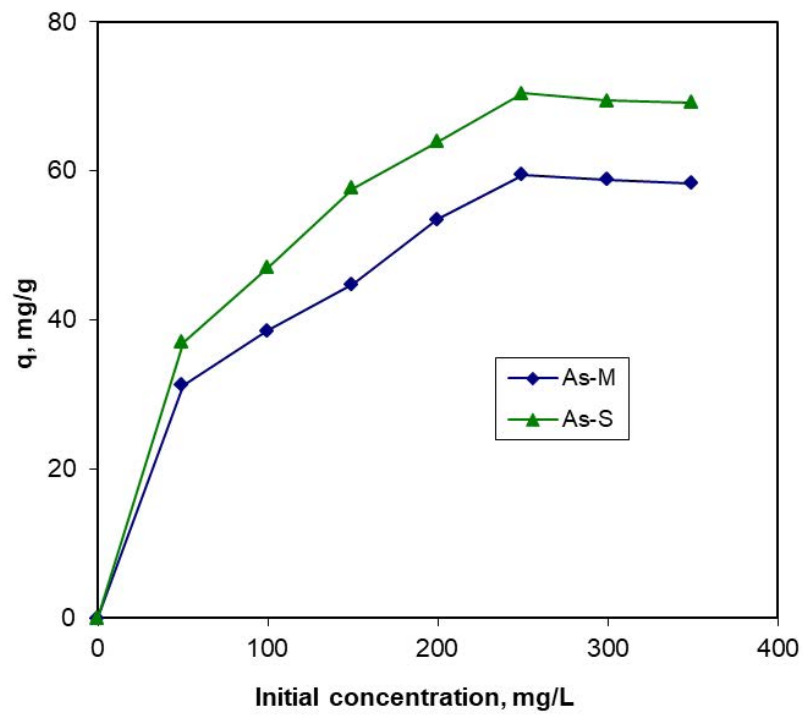

Figure 4. Effect of initial concentration of $\mathrm{As}(\mathrm{V})$ on the adsorption process on mustard husk and soy bran.

this reason, the interaction of $\mathrm{As}(\mathrm{V})$ ions with the adsorbents was amplified.

\section{5. Effect of the Temperature on the Adsorption of $\mathrm{As}(\mathrm{V})$}

The effect of temperature on the adsorption process of the $\mathrm{As}(\mathrm{V})$ on the mustard husk and soy bran was investigated from the range of $25-45^{\circ} \mathrm{C}$. All the other parameters have been kept constant and the results are depicted in Figure 5.

Figure 5 indicated that with the increasing of the temperature adsorption capacity of the adsorbents increase due to the increasing of the attractive forces between adsorbents surface and arsenic ions that is typical for the adsorption of most metal ions from their solutions

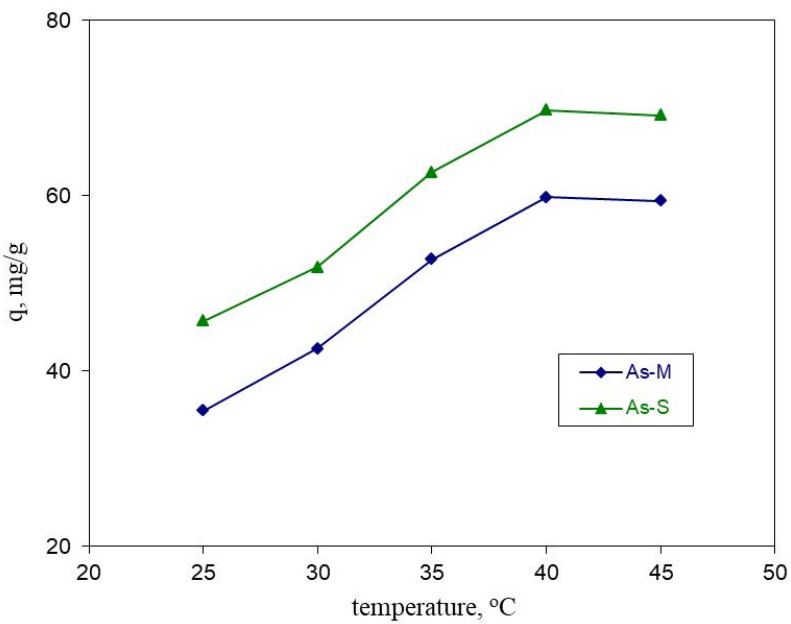

Figure 5. Effect of temperature on the adsorption process of $\mathrm{As}(\mathrm{V})$ on the mustard husk and soy bran. 
onto natural materials. ${ }^{38,39}$ Rate of the adsorbate's molecules distribution along the external layer, as well as in the internal pores of the adsorbent increases with the increasing of temperature.

\section{6. Thermodynamic Parameters}

Determination of the thermodynamic parameters: enthalpy $\left(\Delta \mathrm{H}^{\circ}\right)$, entropy $\left(\Delta \mathrm{S}^{\circ}\right)$, and free Gibbs energy $\left(\Delta \mathrm{G}^{\mathrm{o}}\right)$, was based on experiments performed in a batch system, at temperatures between $25-45^{\circ} \mathrm{C}$.

For this reason equations (3) and (4) have been applied.

$$
\begin{aligned}
\ln K_{d} & =\frac{\Delta S^{0}}{R}-\frac{\Delta H^{0}}{R T} \\
\Delta G^{0} & =\Delta H^{0}-T \Delta S^{0}
\end{aligned}
$$

where: $K_{d}$ is distribution coefficient for adsorption that was calculated with the equation (2).

$\Delta \mathrm{H}^{\circ}$ and $\Delta \mathrm{S}^{\circ}$ values have been estimated from the slope and intercept of the plot of $\ln \mathrm{K}_{\mathrm{d}}$ versus $1 / \mathrm{T}$ (Figure $6)$. The obtained results are presented in Table 1.

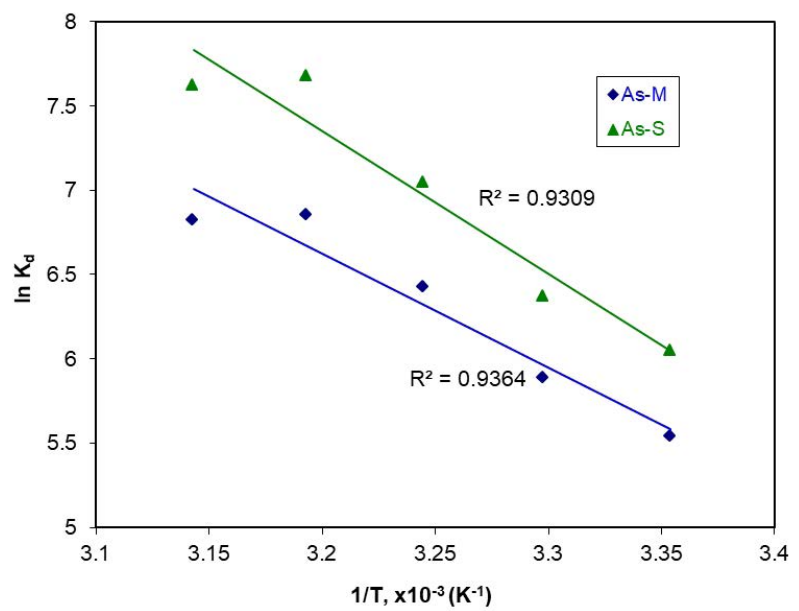

Figure 6. Plot of $\operatorname{lnKd}$ function of $1 / \mathrm{T}$.

The data from Table 1 reveal that $\Delta \mathrm{H}^{\circ}$ and $\Delta \mathrm{S}^{\circ}$ have positive values which indicates the sorbent's affinity for arsenic (V) ions and the adsorption is an endothermic process. The positive values of entropy suggest an increase in the disorder degree in the system. The spontaneity of the adsorption process is confirmed by the negative value of Gibbs energy. This parameter values decrease with the increasing of temperature which indicates the efficiency of adsorption at higher temperature.

The activation energy of the adsorption process $\left(\mathrm{E}_{\mathrm{a}}\right)$ was obtained from the slope of plotting $\ln (1-\theta)$ vs. $1 / \mathrm{T}$, where sorbent surface coverage $(\theta)$ was calculated using the equation (Eq. 5):

$$
\theta=\left(1-\frac{\mathrm{C}}{\mathrm{C}_{0}}\right)
$$

$\mathrm{C}, \mathrm{C}_{0}$ are final and initial concentration of arsenic in aqueous solution $(\mathrm{mg} / \mathrm{L})$.

According to the modified Arrhenius equation, ${ }^{40}$ the plot of $\ln (1-\theta)$ vs. $1 / \mathrm{T}$ gives a straight line with the slope $\mathrm{E}_{\mathrm{a}} / \mathrm{R}$. Activation energy values were calculated from the slope of plot and have values of $59.38 \mathrm{~kJ} \mathrm{~mol}^{-1}$ and $31.97 \mathrm{~kJ}$ $\mathrm{mol}^{-1}$ for mustard husk and soy bran, respectively. The positive values of $\mathrm{E}_{\mathrm{a}}$ were consistent with the positive values of $\Delta \mathrm{H}^{\circ}$ and confirm once again the endothermic nature of the adsorption process.

\section{7. Kinetic Models}

In order to obtain information on the mechanism of adsorption of arsenic on soy bran and mustard husk three different models were applied, that is: the pseudo-first order model (Eq. 6), pseudo-second order model (Eq. 7) and the intraparticle diffusion model (Eq. 8). ${ }^{41-43}$ A relatively high correlation coefficients value indicates that the model successfully describes the kinetics of arsenic adsorption.

$$
\begin{aligned}
& \log \left(\mathrm{q}_{\mathrm{e}}-\mathrm{q}_{\mathrm{t}}\right)=\log \mathrm{q}_{\mathrm{e}}-\frac{\mathrm{k}_{1}}{2.303} \mathrm{t} \\
& \frac{1}{\mathrm{q}_{\mathrm{t}}}=\frac{1}{\mathrm{k}_{2} \mathrm{q}_{\mathrm{e}}^{2}}+\frac{1}{\mathrm{q}_{\mathrm{e}}} \mathrm{t} \\
& \mathrm{q}_{\mathrm{t}}=\mathrm{k}_{\mathrm{id}} \mathrm{t}^{1 / 2}+\mathrm{C}_{\mathrm{d}}
\end{aligned}
$$

where: $\mathrm{q}_{\mathrm{t}}$ and $\mathrm{q}_{\mathrm{e}}$ and are the amounts of arsenic adsorbed

\begin{tabular}{|c|c|c|c|c|c|c|c|}
\hline \multirow[t]{2}{*}{ Sorbent } & \multirow{2}{*}{$\begin{array}{c}\Delta \mathrm{H}^{\mathrm{o}}, \\
\mathrm{kJ} \mathrm{mol}^{-1}\end{array}$} & \multirow{2}{*}{$\begin{array}{c}\Delta S^{o}, \\
\mathrm{~J}^{\mathrm{mol}^{-1}} \mathrm{~K}^{-1}\end{array}$} & \multicolumn{5}{|c|}{$\Delta \mathrm{G}^{\mathrm{o}}, \mathrm{kJ} \mathrm{mol}^{-1}$} \\
\hline & & & $25^{\circ} \mathrm{C}$ & $30^{\circ} \mathrm{C}$ & $35^{\circ} \mathrm{C}$ & $40^{\circ} \mathrm{C}$ & $45^{\circ} \mathrm{C}$ \\
\hline \multicolumn{8}{|l|}{ Mustard } \\
\hline husk & 56.04 & 234.39 & -13.84 & -15.01 & -16.18 & -17.35 & -18.52 \\
\hline Soy bran & 70.36 & 286.27 & -14.98 & -16.41 & -17.84 & -19.27 & -20.70 \\
\hline
\end{tabular}
$\left(\mathrm{mg} \mathrm{g}^{-1}\right)$ at time $\mathrm{t}$ and at equilibrium, respectively, $\mathrm{k}_{1}$ is the rate constant of pseudo-first order kinetic $\left(\mathrm{min}^{-1}\right), \mathrm{k}_{2}$ is the rate constant of pseudo-second order kinetic $\left(\mathrm{g} \mathrm{mg}^{-1} \mathrm{~min}^{-}\right.$ ${ }^{1}$ ), and $\mathrm{k}_{\mathrm{id}}$ is the intra-particle diffusion rate constant (mg

Table 1. Thermodynamic parameters for the adsorption of arsenic (V) on mustard husk and soy bran. 
$\left.\mathrm{g}^{-1} \min ^{-0.5}\right)$. The plot of $\log \left(\mathrm{q}_{\mathrm{e}}-\mathrm{q}_{\mathrm{t}}\right) v s$. time (Figure 7) give a linear relationship from which $k_{1}$ and $q_{e}$ can be determined from the slope and intercept, respectively.
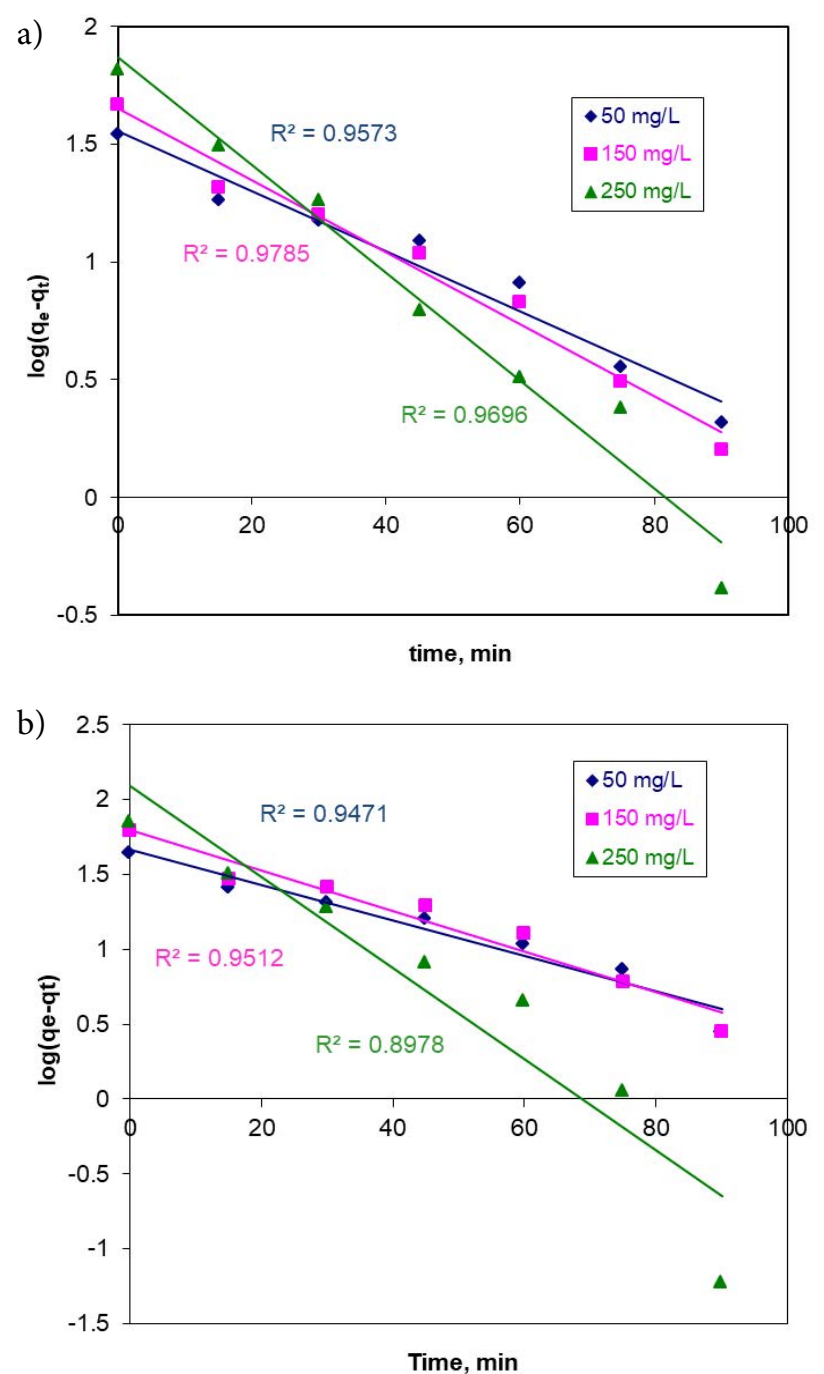

Figure 7. The pseudo-first order kinetics of arsenic (V) adsorption on mustard husk (a) and soy bran (b).
The plot of $\left(\mathrm{t} / \mathrm{q}_{\mathrm{t}}\right) v s$. time (Figure 8) gives a linear relationship from which $\mathrm{q}_{\mathrm{e}}$ and $\mathrm{k}_{2}$ can be determined from the slope and intercept of the plot, respectively.
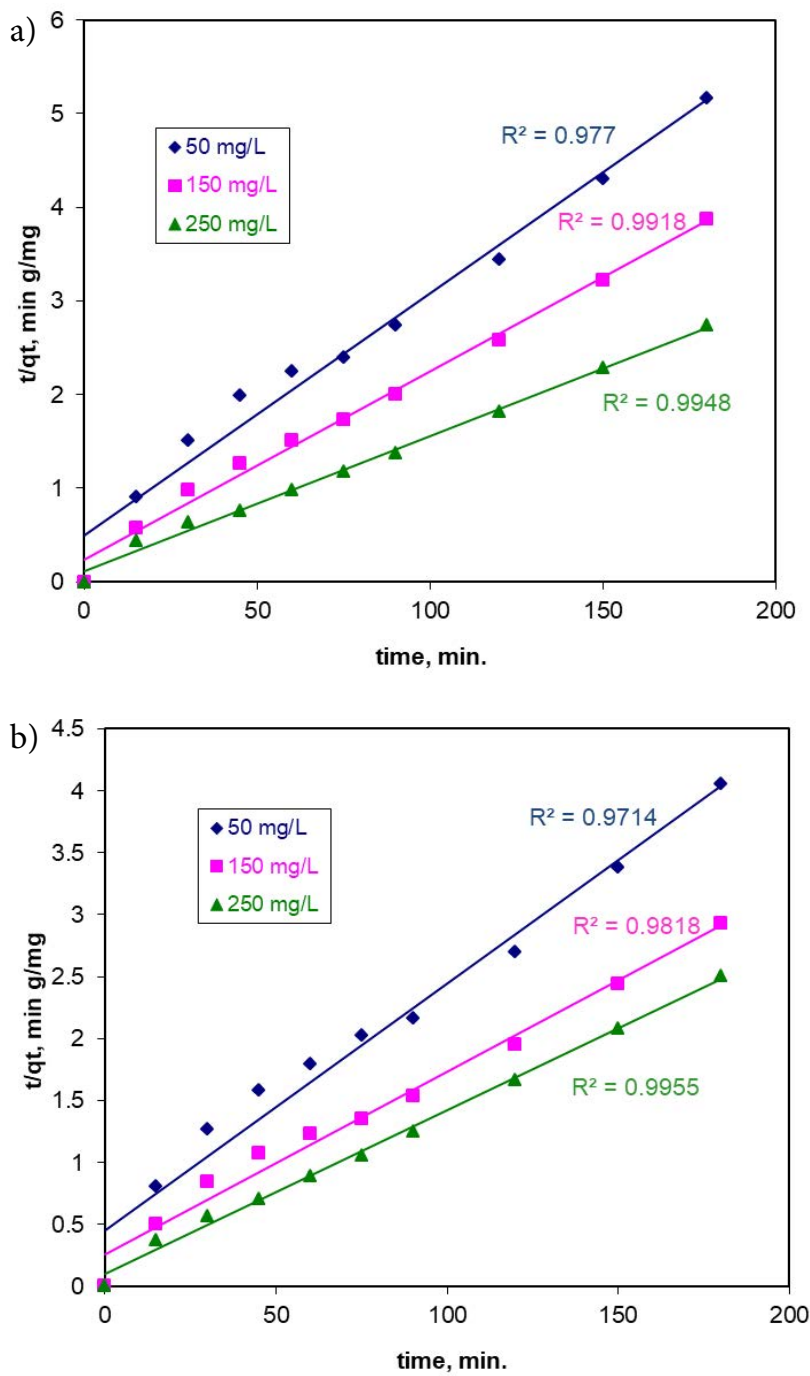

Figure 8. The pseudo-second order kinetics of arsenic (V) adsorption on mustard husk (a) and soy bran (b).

Table 2. Kinetic parameters for the adsorption of arsenic on mustard husk and soy bran.

Model

50

\section{Initial concentration, $\mathrm{mg} / \mathrm{L}$}

150

250

Mustard husk Soy bran Mustard husk Soy bran

\section{Pseudo-first order}

$\mathrm{q}_{\mathrm{e}, \exp }\left(\mathrm{mg} \mathrm{g}^{-1}\right)$

$\mathrm{q}_{\mathrm{e}, \text { calc }}\left(\mathrm{mg} \mathrm{g}^{-1}\right)$

$\mathrm{k}_{1}\left(\min ^{-1}\right)$

$\mathrm{R}^{2}$

Mustard husk Soy bran

Mustard husk

44.66

46.08

35.70

$2.7 \cdot 10^{-2}$

$3.52 \cdot 10^{-2}$

0.979

46.52

49.75

50.0

38.76

$8.88 \cdot 10^{-4}$

$1.71 \cdot 10^{-3}$

0.992

0.971

61.43
62.23
$3.1 \cdot 10^{-2}$
0.951

65.79

$73.63 \quad 122.71$

$5.25 \cdot 10^{-2} \quad 7.0 \cdot 10^{-2}$

0.969

0.898

$\mathrm{q}_{\mathrm{e}, \exp }\left(\mathrm{mg} \mathrm{g}^{-1}\right)$

$\mathrm{k}_{2}\left(\mathrm{~g} \mathrm{mg}^{-1} \mathrm{~min}^{-1}\right)$

$\mathrm{R}^{2}$

0.977
61.43

67.56

$8.6 \cdot 10^{-4}$

0.918

65.79

71.94

75.75

$1.78 \cdot 10^{-3} \quad 1.77 \cdot 10^{-3}$

0.995 
An intra-particle diffusion model was used to predict the rate controlling step but in this case a non-linear relationship has been obtained. The pseudo-first-order and pseudo-second-order rate constants determined are listed in Table 2 along with the corresponding correlation coefficients. From these results it can be seen that the values of correlation coefficient decreases from pseudo second-order to pseudo first-order.

\section{8. Adsorption Isotherms}

It is well known that the adsorption isotherms express the interaction between the adsorbent and adsorbate in the adsorption processes. In order to study the adsorption of arsenic ions on the two sorbents, Langmuir, Freundlich, Temkin and Flory-Huggins adsorption models have been used.

Langmuir isotherm characterizes a monolayer adsorption on a surface with a finite number of identical centers which are homogeneously distributed on the surface of the sorbent. In our study a linearized Langmuir isotherm form (Eq. 9) has been used: ${ }^{44}$

$$
\frac{C_{e}}{q_{e}}=\frac{1}{K_{L} \cdot q_{m}}+\frac{C_{e}}{q_{m}}
$$

where: $\mathrm{q}_{\mathrm{e}}$ represents the amount of adsorbed arsenic per sorbent unit $\left(\mathrm{mg} \mathrm{g}^{-1}\right) ; \mathrm{C}_{\mathrm{e}}$ is arsenic ion concentration at equilibrium $\left(\mathrm{mg} \mathrm{L}^{-1}\right) ; \mathrm{q}_{\mathrm{m}}$ is a parameter that express the maximum adsorption capacity $\left(\mathrm{mg} \mathrm{g}^{-1}\right)$ corresponding to monolayer coverage; $\mathrm{K}_{\mathrm{L}}$ is constantly referring to the adsorption energy $\left(\mathrm{g} \mathrm{L}^{-1}\right)$.

$\mathrm{K}_{\mathrm{L}}$ and $\mathrm{q}_{\mathrm{m}}$ parameters values were calculated from the intercept and the slope of the plot $\mathrm{C}_{\mathrm{e}} / \mathrm{q}_{\mathrm{e}} v s$. $\mathrm{C}_{\mathrm{e}}$ (Figure 9).

An important characteristic of Langmuir isotherms can be expressed by the dimensionless constant (Eq.10) called equilibrium parameter or separation factor.

$$
\mathrm{R}_{\mathrm{L}}=\frac{1}{1+\mathrm{K}_{\mathrm{L}} \mathrm{C}_{0}}
$$

where: $\mathrm{K}_{\mathrm{L}}$ is the Langmuir constant, $\mathrm{C}_{0}$ is the initial concentration of $\mathrm{As}(\mathrm{V})$ ions $\left(\mathrm{mg} \mathrm{L}^{-1}\right)$. For a favorable adsorption process $R_{L}$ value must be between 0 and 1 . In our study $R_{L}$ obtained values were less than one (Table 3 ) which indicates that the $\operatorname{arsenic}(\mathrm{V})$ adsorption process was favorable.

The Freundlich isotherm is based on the multilayer adsorption that means a heterogeneous surface of the sorbent and a non-uniform distribution of heat of adsorption. ${ }^{45}$

A logarithmic form of this model (Eq. 11) was applied in our study:

$$
\log \mathrm{q}_{\mathrm{c}}=\log \mathrm{K}_{\mathrm{F}}+\frac{1}{\mathrm{n}} \log \mathrm{C}_{\mathrm{c}}
$$

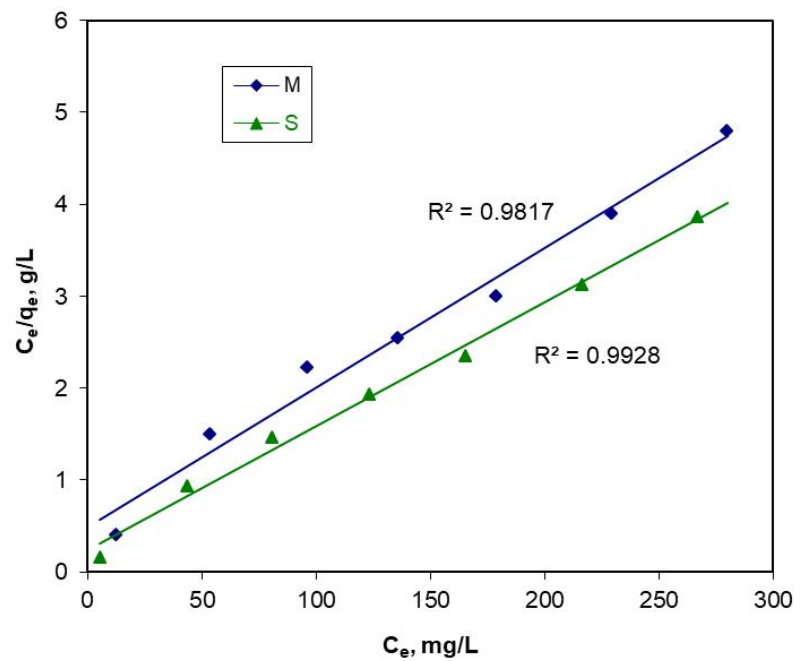

Figure 9. Langmuir isotherms for the $\operatorname{arsenic}(\mathrm{V})$ adsorption on mustard husk and soy bran.

In the above equation, $\mathrm{q}_{\mathrm{e}}$ and $\mathrm{C}_{\mathrm{e}}$ have the same meaning as in $\mathrm{Eq}(9) ; \mathrm{K}_{\mathrm{F}}\left(\mathrm{mg}^{(1-1 / \mathrm{n})} \mathrm{L}^{1 / \mathrm{n}} \mathrm{g}^{-1 / \mathrm{n}}\right)$ and $\mathrm{n}$ are Freundlich constants that indicate the relative adsorption capacity of the sorbent, and the adsorption intensity, respectively.

The slope and intercept of Freundlich model (Figure 10) have been used to calculate $K_{F}$ and factor $n$. A value for $1 / \mathrm{n}$ less than 1 indicates a normal isotherm while $1 / n>1$ suggests a cooperative adsorption. In the case of arsenic adsorption on both mustard husk and soy bran $1 / \mathrm{n}$ values are 0.233 and 0.179 , respectively, indicating a normal isotherm adsorption.

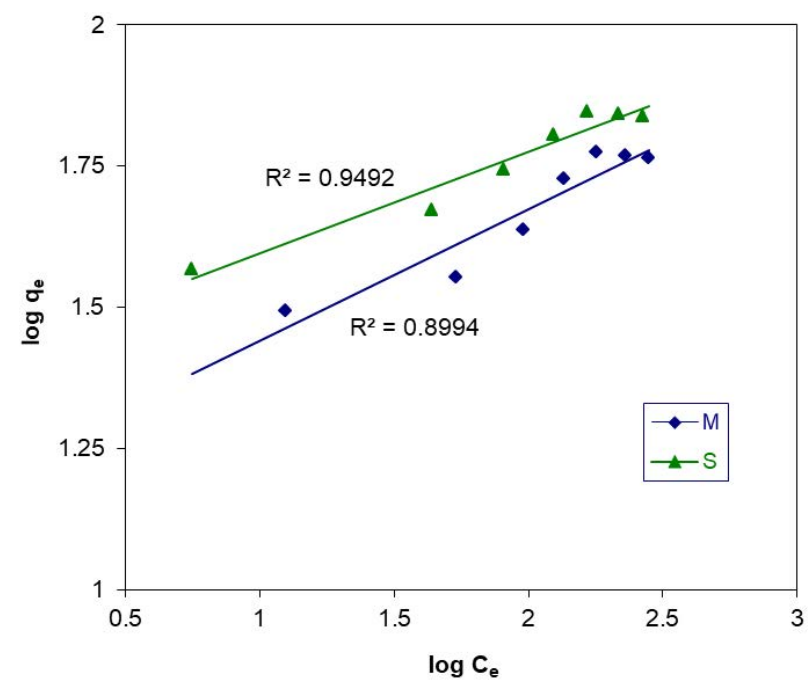

Figure 10. Freundlich isotherms for the arsenic (V) adosrption on mustard husk and soy bran.

The third adsorption isotherm model used in the present work was the Temkin model. In this case, the main assumption is that the heat of adsorption decreases linearly with coverage due to sorbent-sorbate interactions. ${ }^{46}$ The 
linear Temkin isotherm equation (Eq. 12) used in our study was:

$$
\mathrm{q}_{\mathrm{e}}=\mathrm{B} \ln \mathrm{A}+\mathrm{B} \ln \mathrm{C}_{\mathrm{e}}
$$

where: $\mathrm{A}$ is the equilibrium constant $\left(\mathrm{L} \mathrm{g}^{-1}\right)$ corresponding to the maximum binding energy and constant $\mathrm{B}\left(\mathrm{J} \mathrm{mol}^{-1}\right)$ is correlated to the heat of adsorption as follows:

$$
\mathrm{B}=\mathrm{RT} / \mathrm{b}_{\mathrm{T}}
$$

where: $b_{T}$ is the Temkin isotherm energy constant ( $J$ $\left.\mathrm{mol}^{-1}\right)$ and $\mathrm{R}$ is the universal gas constant $\left(8.3146 \mathrm{~J} \mathrm{~mol}^{-1}\right.$ $\mathrm{K}^{-1}$ ). The Temkin isotherm plots for both sorbents are presented in Figure 11 and the isotherm parameters extracted are listed in Table 3.

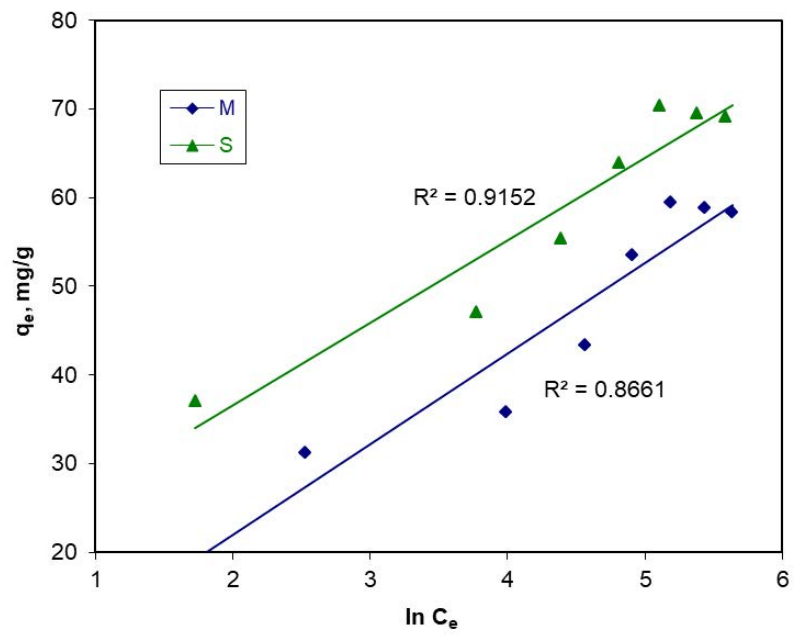

Figure 11. Temkin isotherms for the adsorption of arsenic (V) on mustard husk and soy bran.

For a most comprehensive characterization of the arsenic $(\mathrm{V})$ adsorption process was used the fourth adsorption model, Flory-Huggins, in order to calculate the surface coverage of sorbent by sorbate. ${ }^{47}$

$$
\log \frac{\theta}{\mathrm{C}_{0}}=\log \mathrm{K}_{\mathrm{FH}}+\mathrm{n} \log (1-\theta)
$$

where $\theta$ represents surface coverage and was calculated by Eq. (5), $\mathrm{K}_{\mathrm{FH}}$ is equilibrium constant of the adsorption pro- cess. The parameters of equation (14) were calculated from the slope and intercept of the plot $\log \theta / \mathrm{C}_{0} v s \cdot \log (1-\theta)$ that is depicted in Figure 12 and are presented in Table 3.

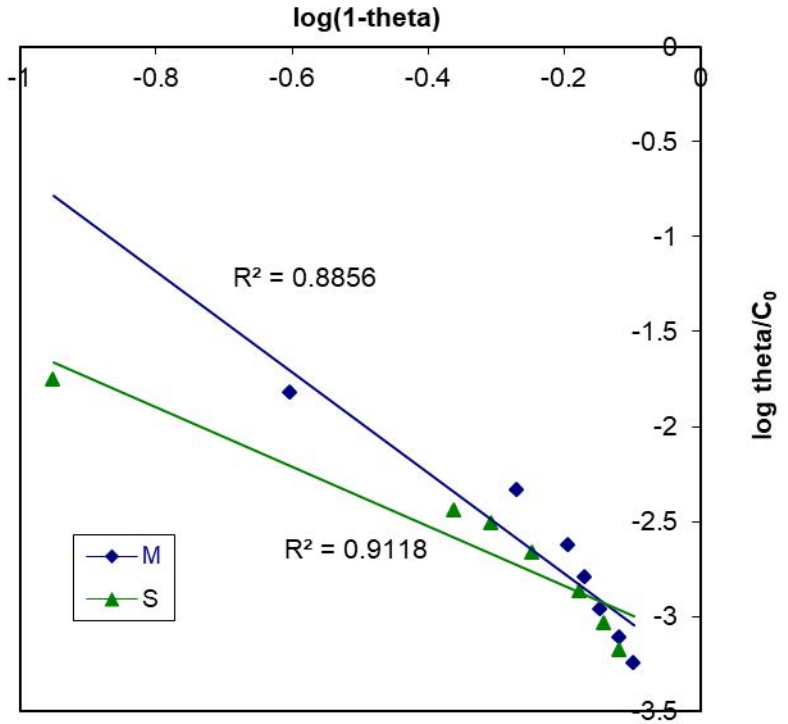

Figure 12. Flory-Huggins isotherms for the arsenic adsorption on mustard husk and soy bran.

Considering all extracted parameters for all four adsorption isotherm models (see Table 3 ) it can be concluded that for the arsenic (V) adsorption on the mustard husk and soy bran the best fit shows the Langmuir isotherm model. In addition, between the two analyzed materials, in terms of adsorption capacity the best candidate seems to be soy bran than of the mustard husk for arsenic (V). The efficiency of the two studied sorbents, soy bran and mustard husk, on the arsenic $(\mathrm{V})$ was highlighted by a comparison with the results from the literature for other sorbents (Table 4). As can be observed the adsorption capacity of the investigated sorbents for the arsenic $(\mathrm{V})$ is higher compared with some other sorbents and its low cost and abundance make it as possible materials for the use in residual waters decontamination.

The fact that in the sorption stage there are a series of processes that can affect the morphology of the adsorbent materials is pointed out by the images obtained by using a Electronic Scanning Microscope, SEM Quanta 250. Imag-

\begin{tabular}{|c|c|c|c|c|c|c|c|c|c|c|c|c|c|}
\hline \multirow[t]{2}{*}{ Sorbent } & \multicolumn{4}{|c|}{ Langmuir } & \multicolumn{3}{|c|}{ Freundlich } & \multicolumn{3}{|c|}{ Flory-Huggins } & \multicolumn{3}{|c|}{ Temkin } \\
\hline & $\underset{\left(\mathrm{mg} \mathrm{g}^{-1}\right)}{\mathrm{q}_{\mathrm{m}}}$ & $\begin{array}{c}\mathbf{K}_{\mathrm{L}} \\
\left(\mathbf{L ~}^{-1}\right)\end{array}$ & $\mathbf{R}^{2}$ & $\mathbf{R}_{\mathbf{L}}$ & $\mathbf{K}_{\mathrm{F}}$ & $\mathbf{n}$ & $\mathbf{R}^{2}$ & $\mathbf{K}_{\mathrm{FH}}$ & n & $\mathbf{R}^{2}$ & A & $\mathbf{b}_{\mathrm{T}}$ & $\mathbf{R}^{2}$ \\
\hline $\begin{array}{l}\text { Mustard } \\
\text { husk }\end{array}$ & 65.79 & 0.032 & 0.982 & 0.111 & 16.15 & 4.29 & 0.899 & $1.99 \cdot 10^{3}$ & 1.565 & 0.886 & 1.158 & 242.21 & 0.866 \\
\hline Soy bran & 74.07 & 0.058 & 0.993 & 0.065 & 26.09 & 5.56 & 0.949 & $1.29 \cdot 10^{3}$ & 2.647 & 0.911 & 0.648 & 265.57 & 0.915 \\
\hline
\end{tabular}
es presents the morphology of sorbens samples (Figure 13)

Table 3. Parameters for the adsorption models. 

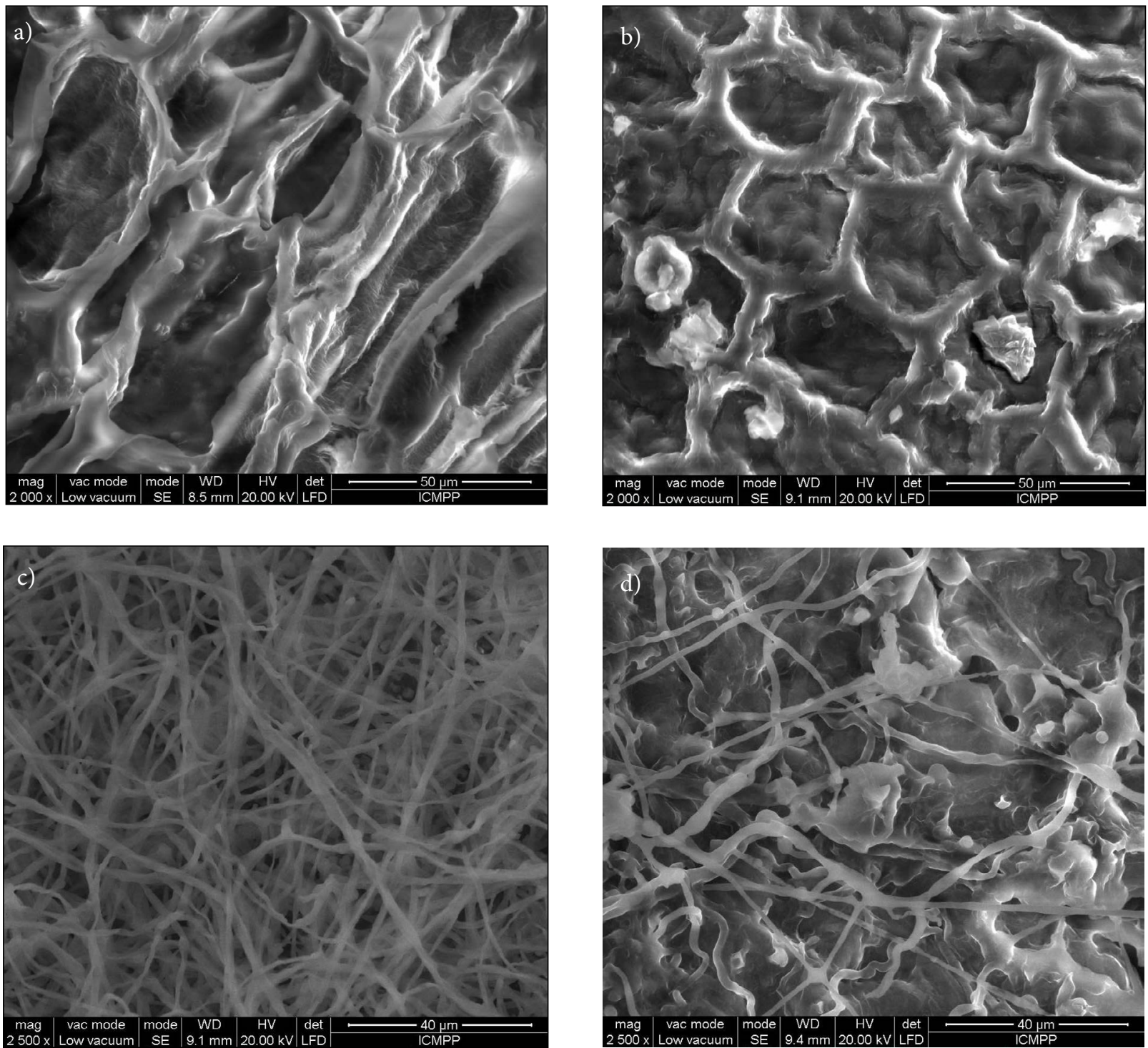

Figure 13. SEM images of the mustard husk and soy bran before (a, c) and after (b, d) adsorption experiments.

Table 4. Comparison of maximum adsorption capacity of different sorbents towards arsenic (V).

\begin{tabular}{lcc}
\hline Sorbent & $\mathbf{q}_{\mathbf{m}}\left(\mathbf{m g ~}^{\mathbf{- 1}}\right)$ & Reference \\
\hline Rice polish & 0.15 & 48 \\
Rice husk & 0.225 & 25 \\
Coconut shell carbon & 2.40 & 49 \\
Pine leaves & 3.27 & 24 \\
Tea fungal biomass & 4.95 & 48 \\
Polymeric alginate beads & 8.33 & 50 \\
Coconut coir pith & 13.75 & 51 \\
Withania frutescens & 16.88 & 52 \\
Calami rhizoma & 22.04 & 52 \\
Orange juice residue & 67.43 & 53 \\
Mustard husk & 65.79 & This work \\
Soy bran & 74.07 & This work \\
\hline
\end{tabular}

before and after adsorption processes with enlarge X2500, scale $40 \mu \mathrm{m}$.

\section{9. Desorption Results}

Once the sorbent is used, it needs to be regenerated. Desorption processes are important from two points of view: first, to recover metal ion and its subsequent use in industrial and secondly, in the regeneration of sorbent for new use processes.

The amount of As released from the sorbent was determined by HG-AAS and the percentage of arsenic desorbed was calculated with equation Eq. 15:

$$
\text { desorbed ion } \%=\frac{\text { amount }_{d e s}}{\text { amount }_{\text {ads }}} \cdot 100
$$


where: amount $t_{\text {des }}$ is the amount of desorbed arsenic and amount $_{\text {ads }}$ is the amount of arsenic adsorbed by the sorbent. The results of desorption experiments reveal that the best regeneration eluent may be aqueous solution of $\mathrm{NaOH}$ $0.01 \mathrm{M}, 87.95 \%$ for mustard husk and $90.67 \%$ for soy bran, respectively.

\section{Conclusions}

The adsorption of arsenic $(\mathrm{V})$ ions on mustard husk and soy bran was studied as a function of contact time, initial arsenic ion concentration, $\mathrm{pH}$, sorbent mass and temperature, the conclusion being that the sorption capacity of the soy bran was higher than that of mustard husk.

The thermodynamic parameters indicate that adsorption of arsenic $(\mathrm{V})$ ions on mustard husk and soy bran is a spontaneous $\left(\Delta \mathrm{G}^{\circ}<0\right)$ and endothermic $\left(\Delta \mathrm{H}^{\circ}>0\right)$ process.

This study indicates that arsenic $(\mathrm{V})$ adsorption is better described by Langmuir isotherm model and the kinetic of the process obeys the pseudo second-order model.

The results obtained in desorption studies showed that, in order to recover arsenic (V) ions a $0.01 \mathrm{M} \mathrm{NaOH}$ solution may be used.

This study reveals the potential of using mustard husk and soy bran as excellent low-cost adsorbent for the removal of arsenic $(\mathrm{V})$ from aqueous solutions.

\section{References}

1. B. K. Mandal, K. T. Suzuki, Talanta 2002, 58, 201-235. DOI:10.1016/S0039-9140(02)00268-0

2. J. Matschullat, Sci. Total Environ. 2000, 249, 297-312. DOI:10.1016/S0048-9697(99)00524-0

3. J. O. Nriagu, J. M. Azcue, Arsenic: historical perspectives. In: Nriagu JO, Ed. Arsenic in the environment. Part I: Cycling and characterization. New York: John Wiley and Sons Inc, 1990, pp. 1-15.

4. A. K. Sharma, J. C. Tjell, J. J. Sloth, P. E. Holm, Appl. Geochem. 2014, 41, 11-33. DOI:10.1016/j.apgeochem.2013.11.012

5. M. Dinesh, C. U. Pittman, J. Hazard. Mater. 2007, 142, 2-53. DOI:10.1016/j.jhazmat.2007.01.006

6. E. T. Mackenzie, R. J. Lantzy, V. Paterson, J. Int. Assoc. Math. Geol. 1979, 6, 99-142. DOI:10.1007/BF01028961

7. N. N. Greenwood, A. Earnshaw, Chemistry of Elements. Pergamon Press, Oxford, 1984, pp. 547-596.

8. Agency for Toxic Substances and Disease Registry, Toxicological Profile for Arsenic, US Public Health Service; US Department of Health and Human Services, Atlanta, 1993.

9. Environmental Protection Agency, Integrated Risk Information System on Arsenic 1995.

10. C. K. Jain, I. Ali, Water Res. 2000, 34, 4304-4312. DOI:10.1016/S0043-1354(00)00182-2

11. World Health Organisation, Environmental health criteria, arsenic. Geneva, 2001.
12. J. C. Ng, J. Wang, A. Shraim, Chemosphere 2003, 52, 13531359. DOI:10.1016/S0045-6535(03)00470-3

13. Y. Jeong, M. Fan, S. Singh, C. L. Chuang, B. Saha, J. H. van Leeuwen, Chem. Eng. Proc. 2007, 46, 1030-1039.

DOI:10.1016/j.cep.2007.05.004

14. M. C. Ciardelli, H. Xu, N. Sahai, Water Res. 2008, 42, 625-624. DOI:10.1016/j.watres.2007.08.011

15. A. Pinisakul, C. Polpraser, P. Porkplan, J. Satayarirod, Water Sci. Technol 2002, 46, 247-254.

DOI:10.2166/wst.2002.0250

16. A. Bodalo, J. L. Gomez, E. Gomez, A. M. Hidalgo, A. Aleman, Desalination 2005, 180, 277-284.

DOI:10.1016/j.desal.2005.02.008

17. H. Guo, D. Stuben, Z. Berner, Coll. Interf. Sci. 2007, 315, 4753. DOI:10.1016/j.jcis.2007.06.035

18. V. Lenoble, Ph.D Thesis, Laboratoire des Sciences de l'Eau et de l'Environnement, Faculté des Sciences, Limoges, France, 2003.

19. P. Mondal, C.B. Majumder, B. Mohanty, J. Hazard. Mater. 2008, 150, 695-702. DOI:10.1016/j.jhazmat.2007.05.040

20. M. Streat, K. Hellgardt, N. L. R. Newton, Proc. Safety Environm. Prot. 2008, 86, 11-20. DOI:10.1016/j.psep.2007.10.008

21. M. Peter, Ultrapure Water 2005, 22, 42-43. DOI:10.1016/S0015-1882(06)70888-6

22. A. Negrea, L. Lupa, P. Negrea, M. Ciopec, C. Muntean, Buletinul AGIR 2009, 2-3, 44-49.

23. I. A. Oke, N.O. Olarinoye, S. R. A. Adewusi, Adsorption 2008, 18, 73-83. DOI:10.1007/s10450-007-9047-Z

24. U. Shafique, A. Ijaz, M. Salman, W. Zaman, N. Jamil, R. Rehma, A. Javaid, J. Taiwan Inst. Chem. Eng. 2012, 43, 256-263. DOI:10.1016/j.jtice.2011.10.006

25. Z. Asif, Z. Chen, Appl. Water Sci. 2015, 1-10. DOI:10.1007/s13201-015-0323-X

26. M. A. Hossain, H. H. Ngo, W. S. Guo, T. V. Nguyen, Biores. Technol. 2012, 113, 97-101. DOI:10.1016/j.biortech.2011.11.111

27. F. Cerino-Cordova, P. Diaz-Flores, R. Garcia-Reyes, E. Soto-Regalado, R. Gomez-Gonzalez, M. Garza-Gonzalez, E. Bustamante, Int. J. Environ. Sci. Technol. 2013, 1-12. DOI:10.1007/s13762-013-0198-Z

28. B. Nagy, A. Maicaneanu, C. Indolean, S. Burca, L. Silaghi-Dumitrescu, C. Majdik, Acta Chim. Slov. 2013, 60, 263-73.

29. Q. Manzoor, R. Nadeem, M. Iqbal, R. Saeed, T. M. Ansari, Biores Technol, 2013, 132, 446-452.

DOI:10.1016/j.biortech.2013.01.156

30. D. Yadav, M. Kapur, P. Kumar, M. K. Mondal, Process. Saf. Environ., 2015, 94, 402-409 DOI:10.1016/j.psep.2014.09.005

31. S. H. S. Pajaie, S. Archin, G. Asadpour, Civil Eng. J. 2018, 4, 620-634. DOI:10.28991/cej-0309121

32. S. Kamel, H. Abou-Yousef, M. Yousef, M. El-Sakhawy, Carbohydrate Polym. 2012, 88, 250-256.

DOI:10.1016/j.carbpol.2011.11.090

33. D. Humelnicu, M. Ignat, F. Doroftei, Environm. Monit. Assess. 2015, 187, 187-198. DOI:10.1007/s10661-015-4454-1

34. H. M. Anawar, Talanta 2012, 88, 30-42. DOI:10.1016/j.talanta.2011.11.068

35. A. N. Anthemidis, G.A. Zachariadis, J.A. Stratis, Anal. Chim. Acta 2005, 547, 237-242. DOI:10.1016/j.aca.2005.05.039 
36. L. C. Ajjabi, L. Chouba, J. Environ. Manag. 2009, 90, 34853489. DOI:10.1016/j.jenvman.2009.06.001

37. Y. Mamindy-Pajany, C. Hurel, N. Marmier, M. Roméo, C.R. Chimie 2009, 12, 876-881. DOI:10.1016/j.crci.2008.10.012

38. K. H. Chong, B. Volesky, Biotech. Bioeng. 1995, 47, 451-460. DOI:10.1002/bit.260470406

39. U. Kumar, Sci. Res. Essay 2006, 1, 33-37. DOI:10.5958/j.0974-4487.11.1.001

40. C. S. Sundaram, N. Viswanathan, S. Meenakshi, J. Hazard. Mater. 2008, 155, 206-215. DOI:10.1016/j.jhazmat.2007.11.048

41. S. Lagergren, KSvenska Vetenskapsakad Handl 1898, 24, 1-39.

42. G. McKay, Y. S. Ho, Process Biochem. 1999, 34, 451-465. DOI:10.1016/S0032-9592(98)00112-5

43. W. J. Jr. Weber, J. C. Morris, J. Sanit. Eng. Div. ASCE, 1963, 89, 31-59.

44. I. Langmuir, J. Am. Chem. Soc. 1916, 38, 2221-2295. DOI:10.1021/ja02268a002

45. H. Freundlich, Phys. Chem. Soc. 1906, 40, 1361-1368.
46. M. Temkin, Zh. Fiz. Khim. 1941, 15, 296-332. DOI: $10.2307 / 40085313$

47. K. Vijayaraghavan, T. V. N. Padmesh, K. Palanivelu, M. Velan, J. Hazard. Mater. 2006, B133, 304-308.

DOI:10.1016/j.jhazmat.2005.10.016

48. D. Ranjan, M. Talat, S. H. Hasan, J. Hazard. Mater. 2009, 166, 1050-1059. DOI:10.1016/j.jhazmat.2008.12.013

49. L. Lorenzen, J. S. J van Deventer, W. M. Landi, Miner. Eng. 1995, 8, 557-569. DOI:10.1016/0892-6875(95)00017-K

50. T. Dewangan, A. Tiwari, A. K. Bajpai, Toxicol. Environ. Chem. 2009, 91, 1055-1067.

DOI: $10.1080 / 02772240802585012$

51. T. S. Anirudhan, M. R. Unnithan, Chemosphere 2007, 66, 60-66. DOI:10.1016/j.chemosphere.2006.05.031

52. M. Chiban, G. Carja, G. Lehutu, F. Sinan, Arabian J. Chem. 2016, 9, S988-S999. DOI:10.1016/j.arabjc.2011.10.002

53. K. N. Ghimire, K. Inoue, K. Makino, T. Miyajima, Sep. Sci. Technol. 2002, 37, 2785-2799. DOI:10.1081/SS-120005466

\section{Povzetek}

V zadnjem času je velika pozornost namenjena uporabi cenovno ugodnih adsorbentov za čiščenje kontaminiranih voda. S namenom smo preverili potencial sojinih lupin in gorčičnih luščin za odstranjevanje arzena (V) iz odpadnih voda. Preučili smo vpliv procesnih parametrov kot so kontaktni čas, pH vrednost, začetna koncentracija arzena, količina adsorbenta in temperatura na odstranjevanje arzena (V). Termodinamski parametri so pokazali, da je proces pod preučevanimi pogoji spontan in endotermen. Separacijski faktor je bil manjši kot ena kar kaže, da je adsorpcija ugodna. Adsorpcijsko ravnotežje lahko dobro opišemo z Langmuirjevo izotermo z maksimalno kapaciteto vezave arzenovih (V) ionov na sojine lupine $74.07 \mathrm{mg} \mathrm{g}^{-1}$ in na gorčične luščine $65.79 \mathrm{mg} \mathrm{g}^{-1}$. Kinetiko lahko opišemo z reakcijo psevdo-prvega reda. 